\title{
Bibliography of Books and Papers on Spenser and Shakespeare
}

Adelman, Janet. The Common Liar: An Essay on Antony and Cleopatra'. New Haven: Yale University Press, 1973.

Alpers, Paul. What is Pastoral? Chicago: University of Chicago Press, 1996.

Anderson, Judith H. 'The Conspiracy of Realism: Impasse and Vision in King Lear.' Studies in Philology 84.1 (1987): 1-23.

Anderson, Judith H. Words that Matter: Linguistic Perception in Renaissance English. Stanford: Stanford University Press, 1996.

Anderson, Judith H. 'Venus and Adonis: Spenser, Shakespeare, and the Forms of Desire.' Grief and Gender, 700-1700. Ed. Jennifer C. Vaught and Lynne Dickson Bruckner. New York: Palgrave, 2003. 149-60.

Andrews, Michael Cameron. "Music's Sound": A Note on Romeo and Juliet.' Notes and Queries 36 (1989): 32-3.

Ardolino, Frank. 'The Influence of Spenser's Faerie Queene on Kyd's Spanish Tragedy. EMLS 7.3 (2002).

Bakeless, John. The Tragical History of Christopher Marlowe. 2 vols. Cambridge, MA: Harvard University Press, 1942

Baldwin, T. W. 'The Genesis of Some Passages Which Spenser Borrowed from Marlowe.' ELH 3 (1942): 157-87.

Baldwin, T.W. 'The Genesis of Some Passages Which Spenser Borrowed from Marlowe.' ELH 12 (1945): 165.

Barthel, Carol. 'Prince Arthur and Bottom the Weaver: The Renaissance Dream of the Fairy Queen.' Spenser: Classical, Medieval, Renaissance, and Modern. Ed. David A. Richardson. Cleveland: Cleveland State University Press, 1977. 72-83.

Bednarz, James P. 'Imitations of Spenser in A Midsummer Night's Dream.' Renaissance Drama 14 (1983): 79-102.

Blake, N. F. A Grammar of Shakespeare's Language. Houndmills, Basingstoke: Palgrave, 2001.

Blythe, David-Everett. 'Ox-eyed Phebe.' Shakespeare Quarterly 33.1 (1982): 101-2.

Boss, Judith E. 'The Golden Age, Cockaigne, and Utopia in The Faerie Queene and The Tempest.' Georgia Review 26 (1972): 145-55.

Brooks, Harold, ed. A Midsummer Night's Dream. Arden 2. (1979). London: Thomas Learning, 2002. xxxiv-xxxix, lviii-lvii.

Brooks, Harold F. 'Richard III: Antecedents of Clarence's Dream.' Shakespeare Survey: An Annual Survey of Shakespeare Studies and Production 32 (1979): 145-50. 
Brown, James Neil. " "A Calendar, a Calendar! Look in the Almanac". Notes and Queries 27 (1980): 162-5.

Bruce, Donald. 'Spenser's Poetic Pictures: a Vision Of Beauty.' Contemporary Review 288.1680 (2006) 73-86.

Burrow, Colin. William Shakespeare: The Complete Sonnets and Poems. Oxford: Oxford University Press, 2002.

Bush, Douglas. 'Hero and Leander and Romeo and Juliet.' Philological Quarterly 9 (1930): 396-9.

Bush, Douglas. 'Marlowe and Spenser.' Times Literary Supplement (Jan 1, 1938): 12.

Bush, Douglas. 'Notes on Shakespeare's Classical Mythology.' Philological Quarterly 6 (1927): 301.

Campana, Joseph. 'On Not Defending Poetry: Spenser, Suffering, and the Energy of Affect.' PMLA 120.1 (2005): 33-48.

Celovsky, Lisa. 'Early Modern Masculinities and The Faerie Queene.' English Literary Renaissance (2005): 210-47.

Cheney, Patrick. Shakespeare, National Poet-Playwright. Cambridge: Cambridge University Press, 2004.

Cheney, Patrick. " "O, Let My Books Be ... Dumb Presagers": Poetry and Theater in Shakespeare's Sonnets.' Shakespeare Quarterly 52.2 (2001): 222-54.

Cheney, Patrick. 'Shakespeare's Sonnet 106, Spenser's National Epic, and Counter-Petrarchism.' English Literary Renaissance 31 (2001): 331-64.

Coatalen, Guillaume. 'The Faerie Queene, VI.viii.32.1, A Midsummer Night's Dream, II.i.2, and Paradise Lost, IV.538.' Notes and Queries 51 (2004): 360-1.

Coyle, Martin. 'King Lear and The Faerie Queene.' Notes and Queries 31 (1984): 205-7.

Crawford, Charles. 'Edmund Spenser, "Locrine", and "Selimus". ' Notes and Queries 9th ser. 7 (1901): 61-3, 101-3, 142-4, 203-5, 261-3, 3245, 384-6.

Cutts, John P. 'Spenser, Shakespeare, and the "Bloody Babe".' Neuphilologische Mitteilungen (1985): 506-14.

Daniell, David. 'Explorers of the Revelation: Spenser and Shakespeare.' Shakespeare's Christianity: Catholic-Protestant Presence in 'Julius Caesar', 'Hamlet', and 'MacBeth'. Ed Beatrice Bartson. Waco: Baylor University Press, 2006. 19-34.

Dauber, Antionette B. 'Allegory and Irony in Othello.' Shakespeare Survey 40 (1988): 123-44.

Doloff, Steven. 'Francisco, Hamlet, and God's Faithful Sentries.' Notes and Queries 44 (1997): 498.

Donow, Herbert S. A Concordance to the Sonnet Sequences of Daniel, Drayton, Shakespeare, Sidney, and Spenser. Carbondale: Southern Illinois University Press, 1969. 
Dzelzainis, Martin. 'Antony and Cleopatra, I.iii.102-5 and Spenser's Ruines of Rome.' Notes and Queries 45 (1998): 345-6.

Edwards, Philip. 'The Rapture of the Sea.' Shakespearean Continuities. Ed. John Batchelor, Tom Cain, and Claire Lamont. New York: St. Martin's, 1997. 175-89.

Esolen, Anthony. 'Not a Hair Shall Perish.' Touchstone: A Journal of Mere Christianity 20.1 (2007): 34-5.

Fitzpatrick, Joan. 'Shakespeare's Titus Andronicus and Bandello's Novelle as Sources for the Munera Episode in Spenser's Faerie Queene, Book 5, Canto 2.' Notes and Queries 52 (2005): 196-8.

Gibbons, Brian. 'Fabled Cymbeline.' Deutsche Shakespeare-Gesellschaft. West: Jahrbuch, 1987. 78-99. Bochum: Kamp, 1987.

Gough, Melinda J. " "Her filthy feature open showne" in Ariosto, Spenser, and Much Ado about Nothing.' Studies in English Literature 1500-1900 39 (1999): 41-67.

Gray, Henry D. 'Shakespeare's Rival Poet.' Journal of English and Germanic Philology 47 (1948): 365-73.

Greenfield, Sayre N. 'Allegorical Impulses and Critical Ends: Shakespeare's and Spenser's Venus and Adonis.' Criticism 36 (1994): 47598.

Guenther, Genevieve. 'Spenser's Magic, or Instrumental Aesthetics in the 1590 Faerie Queene.' English Literary Renaissance 36.2 (2006): 194 226.

Hadfield, Andrew. 'Tamburlaine as the "Scourge of God" and The First English Life of King Henry the Fifth.' Notes and Queries 50 (2003): 399400.

Haley, David. 'Gothic Armaments and King Hamlet's Poleaxe.' Shakespeare Quarterly 29.3 (1978): 407-13.

Hamlin, William M. 'Making Religion of Wonder: The Divine Attribution in Renaissance Ethnography and Romance.' Renaissance and Reformation 18.4 (1994): 39-51.

Harrison, Thomas P., Jr. 'Aspects of Primitivism in Shakespeare and Spenser.' Studies in English (1941): 39-71.

Harrison, Thomas P. Jr. 'Flower Lore in Spenser and Shakespeare: Two Notes.' Modern Language Quarterly 7 (1946): 175-8.

Hart, Alfred. 'The Growth of Shakespeare's Vocabulary.' Renaissance English Studies 19 (No. 75) (1943): 242-54.

Hart, Alfred. 'Vocabularies of Shakespeare's Plays.' Renaissance English Studies 19 (No. 74) (1943): 128-40.

Hecht, Paul J. 'Spenser Out of His Stanza.' Style 39.3 (2005): 316-35.

Hieatt, A. Kent, and Charles W. Hieatt. 'Shakespeare's Early "Fair".' Notes and Queries 45 (1998): 315-18.

Hieatt, A. Kent, Charles W. Hieatt, and Anne Lake Prescott. 'When Did Shakespeare Write Sonnets 1609?.' Studies in Philology 88.1 (1991): 69-109. 
Hieatt, A. Kent. 'Cymbeline and the Intrusion of Lyric into Romance Narrative: Sonnets, "A Lover's Complaint", Spenser's Ruines of Rome.' Unfolded Tales: Essays on Renaissance Romance. Ed. George M. Logan and Gordon Teskey. Ithaca: Cornell University Press, 1989. 98-118. Hieatt, A. Kent 'Shakespeare, William.' The Spenser Encyclopedia. Gen. Ed. A. C. Hamilton. Toronto: University of Toronto Press, 1990. 641-3.

Hieatt, A. Kent, T. G. Bishop and E. A. Nicholson. 'Shakespeare's Rare Words: "Lover's Complaint", Cymbeline, and Sonnets.' Notes and Queries 34 (June 1987): 219-24.

Hieatt, A. Kent. 'The Genesis of Shakespeare's Sonnets: Spenser's Ruines of Rome: by Bellay.' PMLA 98 (1983): 800-14.

Hieatt, Charles. 'Dating King John: The Implications of the Influence of Edmund Spenser's Ruins of Rome on Shakespeare's Text.' Notes and Queries 35 (1988): 458-63.

Hieatt, Constance B. 'Stooping at a Simile: Some Literary Uses of Falconry.' Papers on Language and Literature 19.4 (1983): 339-60.

Holderness, Graham. " "The Scripture Moveth Us in Sundry Places...”: Strategies of Persuasion in Sixteenth Century Anglican Liturgy.' Reformation \& Renaissance Review: Journal of the Society for Reformation Studies 2 (1999): 20-38.

Hunt, Maurice. 'Wrestling for Temperance: As You Like It and The Faerie Queene, Book II.' Allegorica: A Journal of Medieval and Renaissance Literature 16 (1995): 31-46.

Hutchinson, D.S. Shakespeare and the Poets' War. New York: Columbia University Press, 2001.

Hutchinson, D.S. 'The Cynicism of Jaques: A New Source in Spenser's Axiochus.' Notes and Queries 39 (1992): 328-30.

Iyengar, Sujata. " "Handling Soft the Hurts": Female Healers and Manual Contact in Spenser, Ariosto and Shakespeare.' In Sensible Flesh: On Touch in Early Modern Culture. Ed. Elizabeth D. Harvey. Philadelphia: University of Pennsylvania Press, 2003. 39-61.

Jackson, MacDonald P. 'Indefinite Articles in Titus Andronicus, Peele, and Shakespeare.' Notes and Queries 45 (1998): 308-11.

Jackson, MacDonald P. 'Shakespeare's Sonnet CXI and John Davies of Hereford's Microcosmos (1603).' Modern Language Review 102.1 (2007): 1-10.

Jackson, M.P. 'Echoes of Spenser's Prothalamion as Evidence against an Early Date for Shakespeare's A Lover's Complaint.' Notes and Queries 37 (1990): 180-2.

Jump, John D. 'Spenser and Marlowe.' Notes and Queries 11 (1964): 261-2.

Kay, D.C. 'A Spenserian Source for Shakespeare's Claribel?' Notes and Queries 31 (1984): 217. 
Kinney, Clare R. 'Feigning Female Faining: Spenser, Lodge, Shakespeare, and Rosalind.' Modern Philology 95 (1998): 291-315.

Kuhl, E. P. 'Hercules in Spenser and Shakespeare.' Times Literary Supplement (1954): 860.

Kuin, Roger. 'Two-Part Invention: "Love Ruins" Shakespeares Sonnets.' Chamber Music: Elizabethan Sonnet Sequences and the Pleasure of Criticism. Toronto: University of Toronto Press, 1998. 77-100.

Lancashire, Anne. 'Timon of Athnes: Shakespeare's Dr Faustus.' Shakespeare Quarterly 21.1 (1970): 35-44.

Lever, J. W. 'Venus and the Second Chance.' Shakespeare Survey 15 (1962): 81-8.

Logan, Robert A. Shakespeare's Marlowe: The Influence of Christopher Marlowe on Shakespeare's Artistry. Aldershot: Ashgate, 2007.

Luckyj, Christina. 'Rachel Speght and the "Criticall Reader".' English Literary Renaissance 36.2 (2006): 227-49.

Mack, Peter. Elizabethan Rhetoric: Theory and Practice. Cambridge: Cambridge University Press, 2002.

Maley, Willy. " "This ripping of auncestors": the ethnographic present in Spenser's A View of the State of Ireland.' Textures of Renaissance Knowledge. Ed. Philipa Berry and Margaret Tudeau-Clayton. Manchester: Manchester University Press, 2003. 117-34.

Marder, Louis. 'New Source for Sonnets Discovered in Spenser's Ruines of Rome.' Shakespeare Newsletter 32 (1982): 17-18.

Marx, Steven. "'Fortunate Senex": The Pastoral of Old Age.' SEL: Studies in English Literature, 1500-1900 25.1 (1985): 21-44.

Mayhall, Jane. 'Shakespeare and Spenser: A Commentary on Differences.' Modern Language Quarterly 10 (1949): 356-63.

McCown, Gary M. ' "Runnawayes Eyes” and Juliet's Epithalamium.' Shakespeare Quarterly 27.2 (1976): 150-70.

McEvoy, Jaqueline. 'Prophetic Authority and Error: An Biblical View of the Present State of Ireland.' Renaissance Papers (1998): 1-18.

McPeek, James A. S. 'The Genesis of Caliban.' Philological Quarterly 25 (1946): 378-81.

Merriam, Thomas. 'Linguistic Computing in the Shadow of Postmodernism.' Linguistic and Literary Computing 17.2 (2002): 181-92.

Merriam, Thomas. 'Low Frequency Words, Genre, Date, and Authorship.' Notes and Queries 53 (2006): 495-8.

Merriam, Thomas. 'The Tenor of Marlowe in Henry V.' Notes and Queries 45 (1998): 318-25.

Nearing, Homer, Jr. 'Caesar's Sword (Faerie Queene II. x. 49; Love's Labour's Lost v.ii.615).' Modern Language Notes 63.6 (1948): 403-5.

Neill, Kirby. 'More Ado About Claudio: An Acquittal for the Slandered Groom.' Shakespeare Quarterly 3.2 (1952): 91-107. 
Nohrnberg, James, C. 'Alençon's Dream / Dido's Tomb: Some Shakespearean Music and a Spenserian Muse.' Spenser Studies XXII (2007): 73-102.

Norton-Smith, John. 'Marlowe's Faustus (I. iii, 1-4).' Notes and Queries 25 (1978): 436-7.

Nuttall, A. D. 'Spenser and Elizabethan Alienation.' Essays in Criticism 55.3 (2005): 209-25.

Paglia, Camille. Sexual Personae: Art and Decadence from Nefertiti to Emily Dickinson. New Haven: Yale University Press, 1990.

Peck, D. C. 'Raleigh, Sidney, Oxford, and the Catholics, 1579.' Notes and Queries 25 (1978): 427-31.

Pincombe, Michael. "Classical and Contemporary Sources of the "Gloomy Woods" of Titus Andronicus: Ovid, Seneca, Spenser.' Shakespearean Continuities: Essays in Honor of E.A.J. Honigmann. Ed. John Batchelor, Tom Cain, and Claire Lamont. Basingstoke: Macmillan, 1997. 40-55.

Pirnajmuddin, Hossein. 'Spenser's The Faerie Queene.' The Explicator 64.3 (2006): 132-3.

Potts, Abbie Findlay. Shakespeare and 'The Faerie Queene'. Ithaca: Cornell University Press, 1958.

Potts, Abbie Findlay. 'Hamlet and Gloriana's Knights.' Shakespeare Quarterly 6 (1955): 31-43.

Potts, Abbie F. "Spenserian "Courtesy" and "Temperance" in Much Ado about Nothing.' Shakespeare Association Bulletin 17 (1942): 103.

Prescott, Anne Lake, and A. Kent Hieatt. 'Shakespeare and Spenser.' PMLA 100.5 (1985): 820-2.

Prescott, Anne Lake. 'Complicating the Allegory: Spenser and Religion in Recent Scholarship.' Renaissance and Reformation 25.4 (2001): 9-23.

Quint, David. 'Bragging Rights: Honor and Courtesy in Shakespeare and Spenser.' Creative Imitation: New Essays on Renaissance Literature in honor of Thomas M. Greene. Ed. David Quint, Margaret W. Ferguson, G.W. Pigman III, and Wayne A. Rebhorn. Binghamton: Medieval and Renaissance Texts and Studies, 1992. 391-430.

Rabl, Kathleen. "Taming the "Wild Irish" in English Renaissance Drama.' Literary Interrelations: Ireland, England, and the World. Ed. Wolfgang Zach and Heinz Kosok. Tübingen: G. Narr Verlag, 1987. 47-59.

Reid, Robert L. 'The Fairy Queen: Gloriana or Titania?' The Upstart Crow 13 (1993): 16-32.

Rhu, Lawrence. 'Agons of Interpretation: Ariostan source and Elizabethan Meaning in Spenser, Harington, and Shakespeare.' Renaissance Drama 24 (1993): 171-88.

Ringler, William A., Jr. 'Spenser, Shakespeare, Honor, and Worship.' Renaissance News 14.3 (1961): 159-61. 
Roberts, Gareth, 'Three Notes on Uses of Circe by Spenser, Marlowe and Milton.' Notes and Queries 25 (1978): 433-5.

Roe, John, ed. The Poems. By William Shakespeare. New Cambridge Shakespeare. Cambridge: Cambridge University Press, 1992.

Rosaye, Jean-Paul. 'Tradition and Meaning: One Interpretation of Renaissance Theology in the Twentieth Century.' Reformation \& Renaissance Review: Journal of the Society for Reformation Studies 2 (1999): 9-20.

Sagaser, Elizabeth Harris. 'Shakespeare's Sweet Leaves: Mourning, Pleasure, and the Triumph of Thought in the Renaissance Love Lyric.' English Literary History 61 (1994): 1-26.

Sarrazin, G. 'Wortechos bei Shakespeare I.' Jahrbuch der deutschen Shakespeare-Gesellschaft. 1897. 121-65

Sarrazin, G. 'Wortechos bei Shakespeare II.' Jahrbuch der deutschen Shakespeare-Gesellschaft. 1897. 119-69.

Schmidgall, Gary, and A. Kent Hieatt. 'Shakespeare's Sonnets.' PMLA 99.2 (1984): 244-5.

Schoeneich, Georg. Der litterarische Einfluss Spensers auf Marlowe. Halle: Diss., 1907.

Scott, William O. 'Proteus in Spenser and Shakespeare: The Lover's Identity.' Shakespeare Studies (1965): 283-93.

Sims, James H. 'Perdita's "Flowers O' Th' Spring" and "Vernal Flowers” in Lycidas.' Shakespeare Quarterly 22.1 (1971): 87-90.

Slater, Eliot. 'Shakespeare: Word Links Between Poems and Plays.' Notes and Queries 22 (April 1975): 157-63.

Sokol, B.J. 'A Spenserian Idea in The Taming of the Shrew.' English Studies 66 (1985): 310-15.

Stapleton, M.L. 'Spenser, the Antiquitez de Rome, and the Development of the English Sonnet Form.' Comparative Literature Studies 27.4 (1990): 259-74.

Taylor, A. B. 'Britomart and the Mermaids: A Note on Marlowe and Spenser.' Notes and Queries 18 (1971): 224-5.

Taylor, Anthony Brian. 'The Elizabethan Seneca and Two Notes on Shakespeare and Spenser.' Notes and Queries 34 (1987): 193-5.

Thaler, Alwin. 'Mercutio and Spenser's Phantastes.' Philological Quarterly 16 (1937): 405-7.

Thaler, Alwin. 'Shakespeare and Spenser.' Shakespeare Association Bulletin 10 (1935): 192-211.

Thaler, Alwin. 'Shakespeare and Spenser.' Shakespeare Association Bulletin 11 (1936): 34-40.

Thaler, Alwin. 'Spenser and Much Ado about Nothing.' Studies in Philology 37 (1940): 225-35.

Thomas, Sidney. 'On the Dating of Shakespeare's Early Plays.' Shakespeare Quarterly 39.2 (1988): 187-94. 
Tilley, Morris P. 'The Organic Unity of Twelfth Night.' PMLA 29.4 (1914): 550-66.

Tobin, J.J.M. “"A Calandar, A Calandar! Look in the Almanac.” Notes and Queries 27 (1980): 162-5.

Tobin, J.J.M. 'Malbecco, Yet Again.' Notes and Queries 32 (1985): 478-9.

Tobin, John. 'Spenserian Parallels.' Essays in Criticism: A Quarterly Journal of Literary Criticism 29 (1979): 264-9.

Tosello, Matthew. 'Spenser's Silence about Dante.' Studies in English Literature 17:1 (1977): 59-66.

van Kranendonk, A.G. 'Spenserian Echoes in A Midsummer Night's Dream.' English Studies 14 (1932): 209-11.

Walley, Harold R. 'Shakespeare's Debt to Marlowe in Romeo and Juliet.' Philological Quarterly 21.3 (1942): 257-67.

Watkins, W. B. C. Shakespeare and Spenser. Princeton: Princeton University Press, 1950.

Watkins, W. B. C. 'The Plagiarist: Spenser or Marlowe?' English Literary History 11.4 (1944): 249-65.

Weatherby, H. L. 'Spenser and Shakespeare at Sonnets.' Sewanee Review 108:1 (2000): 124-31.

Weiner, Andrew D. 'Sidney/Spenser/Shakespeare: Influence/Intertextuality/Intention.' Influence and Intertextuality in Literary History. Madison: University of Wisconsin Press, 1991. 245-70.

White, R.S. 'Metamorphosis by Love in Elizabethan Romance, Romantic Comedy and Shakespeare's Early Comedies.' Review of English Studies n.s. 35 (1984): 14-64.

White, R.S. 'Shakespearian Source-Material in Spenser.' Notes and Queries 38 (1991): 60.

Williams, Christopher. 'Hume on the Tedium of Reading Spenser.' British Journal of Aesthetics 46.1 (2006): 1-16.

Woodbridge, Linda. " "Fire in Your Heart and Brimstone in Your Liver:" Towards an Unsaturnalian Twelfth Night.' Southern Review: Literary and Interdisciplinary Essays 17.3 (1984): 270-91.

Worthen, W. B. 'The Weight of Anthony: Staging Character in Anthony and Cleopatra.' Studies in English Literature 26:2 (1986): 295-308.

Yuasa, Nobuyuki. 'The Art of Naming: A Study of Fictional Names as an Element of Style in Chaucer, Spenser and Shakespeare.' Poetica: An International Journal of Linguistic-Literary Studies 41 (1994): 59-83. 